\title{
Awareness of Netizens on Cyber Crimes - An Empirical Examination in Andhra Pradesh
}

\author{
Satish Kumar Ganta, K. I. Pavan Kumar
}

\begin{abstract}
Internet has become an innovative relief for the modern generation, at it also promote a burden on the society. The internet acts as the genesis and breeding ground for a new kind of crime called the "cyber crime". Common internet users are not aware of cyber crimes and they are not conscious on the precautionary aspects to over come such attacks from taking place. This paper aims to analyze the awareness levels of internet users towards various forms of cyber crimes. This study was conducted in Krishna and Guntur districts of Andhra Pradesh. Descriptive Research Design was adopted for the study and a sample size of 160 respondents were selected using Random Sampling Technique involving both the genders among the internet users. The findings of the study shows that the awareness levels of the internet users towards cyber crimes in the study area are very low and they have very less perception towards various forms of cyber crimes that exists in the modern times.
\end{abstract}

KEY WORDS : Cyber Crimes, Awareness, Cyber Law, Internet Users

\section{INTRODUCTION}

The rapid development of computer and information technology have projected into everything and anything in daily life. The globalization process has gained momentum with the advent of internet facility and becoming more dependent wherein the physical boundaries have vanished. The concept of internet formed the genesis for the aspects like information processing and data storing.

The innovative developments in the science of informatics had imbibed both positive and negative concerns for humanity and society. As the value of information in terms of social, economic and political aspects had gained prominence, the individuals who aspire to cross the corners in order to gain both money and power have started to utilize the Information Technology to commit certain crimes, at times even targeting the scientific technology in itself. This point of cross section forms the origin of the term 'Cyber Crime'.

\section{STATEMENT OF THE PROBLEM}

In India, Cyber crime is growing exponentially and many net- using citizens particularly the young aged youth are becoming the victims of cyber crime. This may be due to the reason of lack of proper awareness on the cyber crime activities and lack of proper knowledge on cyber law that

Revised Manuscript Received on October 15, 2019.

Satish Kumar Ganta: Research Scholar, KLU College of Law, KL

Dr.K.I.Pavan Kumar: Assoc.Professor, KLU College of Law, KL University, A.P. University, A.P

exists in the country. Hence, there is an urgent need to conduct a survey on the awareness levels of the internet users with regard to the aspect of cyber crimes.

\section{OBJECTIVES}

1. To study the profile of the respondents towards internet usage practices in the study area.

2. To analyze the awareness levels among the net- users in the study area towards cyber crimes.

\section{RESEARCH METHODOLOGY}

For the purpose of this research study, Descriptive Research design was adopted. Primary data was collected with the help of a Structured Questionnaire. The sample respondents were drawn from Krishna and Guntur Districts of Andhra Pradesh. Random Sampling Technique was followed for drawing the sample from the identified universe. A total sample of 160 respondents were drawn from 2 districts ( 80 respondents from Krishna District and 80 respondents from Guntur District). Among the sample respondents drawn for the study, 80 . respondents were males and 80 respondents were females. The sample details were given in the following table.

Sample Details

\begin{tabular}{|l|l|l|l|}
\hline \multirow{2}{*}{ District } & Category & Sample Size & $\begin{array}{l}\text { Total } \\
\text { Sample } \\
\text { Drawn }\end{array}$ \\
\hline \multirow{2}{*}{ Krishna } & Male & 40 & \multirow{2}{*}{80} \\
\cline { 2 - 4 } & Female & 40 & 80 \\
\hline \multirow{2}{*}{ Guntur } & Male & 40 & 160 \\
\cline { 2 - 4 } & Female & 40 & \multirow{2}{*}{} \\
\hline & Total & - & \multicolumn{2}{|c}{} \\
\hline
\end{tabular}

The identified dimensions for this study are awareness levels of internet users towards the word "Internet" , total hours spent on internet, frequent use of internet, using internet through mobile phones, awareness on cyber crimes, awareness on Information Technology Act 2000, awareness towards various cyber crimes, awareness on computer security system, awareness on computer networks and opinion on role of education in the prevention of cyber crimes. 


\section{DATA ANALYSIS AND DISCUSSION}

Table No.1

Particulars of Respondents on the frequent usage of Internet

\begin{tabular}{|l|l|l|}
\hline $\begin{array}{l}\text { Frequent Internet } \\
\text { Usage }\end{array}$ & No.of Respondents & Percentage \\
\hline Yes & 154 & 96.2 \\
\hline No & 6 & 3.8 \\
\hline Total & 160 & 100 \\
\hline
\end{tabular}

The above table shows particulars of the respondents on the frequent usage of internet. It shows that 96.2 percent of the respondents had opined that they use the internet frequently and only 3.8 percent of the respondents had disclosed that they do not use internet frequently.

Table No. 2

Particulars of Respondents on the Awareness of the word Internet

\begin{tabular}{|l|l|l|}
\hline Awareness & No.of Respondents & Percentage \\
\hline Yes & 148 & 92.5 \\
\hline No & 12 & 7.5 \\
\hline Total & 160 & 100 \\
\hline
\end{tabular}

The table no 2 shows particulars of the respondents on their awareness on the word 'Internet' . It shows that 92.5 percent of the respondents had opined that they are aware of the word 'Internet' and only 7.5 percent of the respondents had disclosed that they are not aware of the word 'Internet'. Table No. 3

Particulars of Respondents on the usage of Internet through Mobile Phones

\begin{tabular}{|l|l|l|}
\hline $\begin{array}{l}\text { Internet Usage } \\
\text { through Mobile } \\
\text { Phones }\end{array}$ & $\begin{array}{l}\text { No.of } \\
\text { Respondents }\end{array}$ & Percentage \\
\hline Yes & 149 & 93.1 \\
\hline No & 11 & 6.9 \\
\hline Total & 160 & 100 \\
\hline
\end{tabular}

The above table shows particulars of the respondents on their usage of internet through mobile phones . It shows that 93.1 percent of the respondents had opined that they use internet through their mobile phones and only 6.9 percent of the respondents had disclosed that they are not using internet through their mobile phones.

Table No.4

Awareness of the respondents towards Cyber Crimes

\begin{tabular}{|l|l|l|}
\hline $\begin{array}{l}\text { Awareness on } \\
\text { Cyber Crimes }\end{array}$ & $\begin{array}{l}\text { No.of } \\
\text { Respondents }\end{array}$ & Percentage \\
\hline Yes & 114 & 71.2 \\
\hline No & 46 & 28.8 \\
\hline Total & 160 & 100 \\
\hline
\end{tabular}

The above table shows particulars of the respondents on their awareness towards cyber crimes. It shows that 71.5 percent of the respondents had opined that they are aware of cyber crimes and 28.8 percent of the respondents had disclosed that they are not aware of cyber crimes.

Table No. 5

Awareness of the Respondents towards Information Technology (IT) Act 2000

\begin{tabular}{|l|l|l|}
\hline $\begin{array}{l}\text { Awareness } \\
\text { towards } \\
\text { IT Act 2000 }\end{array}$ & No.of Respondents & Percentage \\
\hline Yes & 84 & 52.5 \\
\hline No & 76 & 47.5 \\
\hline Total & 160 & 100 \\
\hline
\end{tabular}

The above table shows particulars of the respondents on their awareness towards IT Act 2000 . It shows that 52.5 percent of the respondents had opined that they are aware of the IT Act 2000 and 47.5 percent of the respondents had disclosed that they are not aware of the IT Act 2000 .

Table No. 6

Awareness of the Respondents towards various cyber crimes

\begin{tabular}{|l|l|l|}
\hline $\begin{array}{l}\text { Awareness } \\
\text { towards } \\
\text { Various Cyber } \\
\text { Crimes }\end{array}$ & $\begin{array}{l}\text { No.of } \\
\text { Respondents }\end{array}$ & Percentage \\
\hline Credit card frauds & 8 & 5.0 \\
\hline Cyber Bullying & 4 & 2.5 \\
\hline Cyber Stalking & 6 & 3.8 \\
\hline Cyber Terrorism & 2 & 1.3 \\
\hline Defamation & 3 & 1.8 \\
\hline Denial of Service & 3 & 1.8 \\
\hline Hacking & 36 & 22.5 \\
\hline Identity Theft & 3 & 1.8 \\
\hline Morphing & 5 & 3.2 \\
\hline Online Fraud & 2 & 1.3 \\
\hline Phishing & 13 & 8.1 \\
\hline Spam Mails & 5 & 3.2 \\
\hline No Opinion & 70 & 43.7 \\
\hline Total & 160 & 100 \\
\hline
\end{tabular}

The above table shows particulars of the respondents on their awareness towards various cyber crimes. It shows that 22.5 percent of the respondents are aware of hacking activities, 8.1 percent of the respondents are aware of phishing activities, 5 percent of the respondents are aware of credit card frauds and 3.8 percent of the respondents are aware of cyber stalking. This table further depicts that 43.7 percent of the respondents had no opinion on the aspects of various cyber crimes.

Table No. 7

Awareness of the Respondents on Computer Security System

\begin{tabular}{|l|l|l|}
\hline $\begin{array}{l}\text { Awareness on } \\
\text { Computer } \\
\text { Security System }\end{array}$ & $\begin{array}{l}\text { No.of } \\
\text { Respondents }\end{array}$ & Percentage \\
\hline Yes & 106 & 66.3 \\
\hline No & 54 & 33.7 \\
\hline Total & 160 & 100 \\
\hline
\end{tabular}


The above table shows particulars of the respondents on their awareness towards Computer Security System . It shows that 66.3 percent of the respondents had opined that they are aware of computer security system and 33.7 percent of the respondents had disclosed that they are not aware of computer security system.

Table No. 8

Awareness of the Respondents on Computer Networks

\begin{tabular}{|l|l|l|}
\hline $\begin{array}{l}\text { Awareness on } \\
\text { Computer } \\
\text { Security System }\end{array}$ & $\begin{array}{l}\text { No.of } \\
\text { Respondents }\end{array}$ & Percentage \\
\hline Yes & 76 & 47.5 \\
\hline No & 84 & 52.5 \\
\hline Total & 160 & 100 \\
\hline
\end{tabular}

The above table shows particulars of the respondents on their awareness towards computer networks . It shows that 47.5 percent of the respondents had opined that they are aware of computer security system and 52.5 percent of the respondents had disclosed that they are not aware of computer security system.

Table No.9

Opinion of the Respondents on role of education in the prevention of cyber crimes

\begin{tabular}{|l|l|l|}
\hline $\begin{array}{l}\text { Opinion on the } \\
\text { Role of Education }\end{array}$ & $\begin{array}{l}\text { No.of } \\
\text { Respondents }\end{array}$ & Percentage \\
\hline Yes & 132 & 82.5 \\
\hline No & 28 & 17.5 \\
\hline Total & 160 & 100 \\
\hline
\end{tabular}

The above table shows particulars of the respondents about their opinion on the role of education in the prevention of cyber crimes. It shows that 82.5 percent of the respondents had opined that the education helps in preventing cyber crimes and 17.5 percent of the respondents had disclosed that education may not help in preventing cyber crimes.

\section{CONCLUSION}

The findings of the study shows that the internet users (Netizens) in the selected areas of Andhra Pradesh are not well aware of the cyber - crime aspects. The awareness level of the respondents towards the computer network system and operations is very low. They are not aware of various types of cyber crimes except a few aspects like hacking and credit card frauds. Majority of the respondents are not aware of the aspect of cyber crime. Hence, there is every need on part of the government authorities, Non- government organizations and educational institutions to impart proper knowledge to the internet users on cyber crimes and the existing cyber laws in India.

\section{REFERENCES}

1. Asokhia, M., (2010), Enhancing national development and growth through combating cybercrime internet fraud: A comparative approach, J. Soc. Sci., 23: 13-19.

2. KHAN, M., \& AYYOOB, M. (2017). CYBER SECURITY AND ETHICS ON SOCIAL MEDIA. Journal of Modern Developments in Applied Engineering \& Technology Research, 1(2), 51-58.
3. Yadav, S., \& Siddartha, S. (2018). Fraud Detection of Credit Card by Using HMM Model. IMPACT: International Journal of Research in Engineering \& Technology, 6(1).

4. Bougaardt, G. and M. Kyobe, 2011. Investigating the factors inhibiting SMEs from recognizing and measuring losses from cyber crime in South Africa, Electr. J. Inform. Syst. Evaluat., 14: 167-178.

5. Kumaresan, G., \& Rajakumar, P. (2015). Predictive Analytics Using Big Data: A Survey.

6. Brenner,W.S. (2010), Cybercrime : Criminal threats from cyberspace, Greenwood Publishing group, Westport.

7. Khan, M., \& Ayyoob, M. O. H. A. M. M. A. D. (2017). Computer security in the human life. International Journal of Computer Science and Engineering (IJCSE), 6(1), 35-42.

8. Sherasiya, T., Upadhyay, H., \& Patel, H. B. (2016). A survey: Intrusion detection system for internet of things. International Journal of Computer Science and Engineering (IJCSE), 5(2).

9. Higgins, George (2010), Cybercrime: An Introduction to an Emerging Phenomenon, McGraw Hill Publishing, New York.

10. Yoshida, M., Thammetar, T., \& Duangchinda, V. (2016). Investigation on Using Twitter Communication During a Conference. International Journal of Educational Science and Research (IJESR), 6(3).

11. Yang, H. L., \& Wu, W. P. (2016). The Effects of Consumers' Belief regarding Internet Rumors on Purchasese Intention from Different Spreading Channels. International Journal of Information Systems, Management Research \& Development (IJISMRD), 6(1), 1-8.

12. Welsh, Jennifer (2011). Is Constant 'Facebooking' Bad for Teens? Live science, 6 Aug. 2011. 